\title{
RESULTS OF THE EDITORIAL PROCESS 1999-2008
}

\author{
BY
}

\section{PETER VAN ELS*}

The editorial process at De Economist is a co-operative effort of the editorial board and the managing editor, who is the editorial board's executive member. Papers are received at the Amsterdam office and distributed to two appropriate co-editors, who are then in charge of initiating the refereeing process. The referees make a recommendation for or against publication to the chairman of the editorial board, who is ultimately in charge of the final decision.

As Table 1 indicates, in the years 1999-2008 the editorial process resulted in an average rejection rate of 64\%. Note that the final figure for the 2008 rejection rate may change somewhat as for a number of submissions the refereeing process has not yet been completed. Communications (shorter papers) and special issue articles are not included in the figures.

The duration of the refereeing process relates to the number of months passing between the first submission of the manuscript and the receipt by the authors of the referee reports and the editorial board's accompanying judgement. In the 10 -year period under consideration, the average duration has been 2.7 months.

TABLE 1 - MANUSCRIPTS SUBMITTED AND REJECTED FOR PUBLICATION

\begin{tabular}{lllll}
\hline Year & $\begin{array}{l}\text { Submitted } \\
(1)\end{array}$ & $\begin{array}{l}\text { Rejected } \\
(2)\end{array}$ & $\begin{array}{l}\text { Annual rejection rate } \\
(2):(1)\end{array}$ & $\begin{array}{l}\text { Duration referee process } \\
\text { (months) }\end{array}$ \\
\hline 1999 & 34 & 23 & 0.68 & 3.7 \\
2000 & 26 & 18 & 0.69 & 3.1 \\
2001 & 29 & 15 & 0.52 & 3.0 \\
2002 & 26 & 18 & 0.69 & 2.7 \\
2003 & 28 & 14 & 0.46 & 3.1 \\
2004 & 43 & 25 & 0.58 & 2.6 \\
2005 & 27 & 14 & 0.52 & 2.6 \\
2006 & 30 & 24 & 0.80 & 1.7 \\
2007 & 32 & 23 & 0.72 & 2.1 \\
2008 & 44 & 31 & 0.70 & 2.2 \\
& Total & Total & Average & Average \\
$1999-2008$ & 319 & 205 & 0.64 & 2.7 \\
\hline
\end{tabular}

* Corresponding author: Economics and Research Division, De Nederlandsche Bank, P.O. Box 98, 1000 AB, Amsterdam, The Netherlands; e-mail: p.j.a.van.els@dnb.nl 